\title{
The Effect of School Principal Supervision, Principal Leadership, and Teacher Achievement Motivation on the Performance of Public High School Teachers in Barito Kuala Regency
}

\author{
Ikhsan Budiman *, Sulaiman, M. Saleh \\ Master Program of Education Management, Universitas Lambung Mangkurat, Banjarmasin 70123, \\ Indonesia
}

Article history:

Submission August 2020

Revised August 2020

Accepted September 2020

*Corresponding author:

E-mail:

ikhsanbudiman281@gmail.com

\begin{abstract}
A teacher is one most essential components in teaching and learning in school. Therefore, teachers' performance has an essential role in shaping the quality of education in a school. Theoretically, there are various factors related to performance. This study aims to analyze the Effects of School Principal Supervision, Principal Leadership, and Teacher Achievement Motivation on the Performance of Public High School Teachers in Barito Kuala Regency. This research uses quantitative descriptive methods. A sample of 191 people from 408 teachers spread over 16 high schools in Barito Kuala Regency. Data were extracted using a questionnaire that has been valid and reliable and analyzed using Path Analysis. It showed that: (1) There was a direct influence on the supervision of the principal, leadership of the principal, achievement motivation on teacher performance; and (2) There is an indirect effect between the supervision of school principals through achievement motivation on the performance of high school teachers in Barito Kuala Regency. This study concludes that a significant effect is for all independent variables studied on teacher performance, both directly and indirectly.
\end{abstract}

Keywords: Supervision of school principals, principal leadership, achievement motivation, teacher performance

\section{Introduction}

Education is vital in human life, where humans can foster their personality by developing their potential per the values that exist in society. Education also has a significant role in preparing and developing reliable human resources who can compete in a healthy manner (Alpian, Anggraeni, Wiharti, \& Soleha, 2019). In the education process, the teacher is an essential component at the school level. The quality of teacher performance in schools plays a vital role in achieving school goals (Gusman, 2014); therefore, improving teacher performance is necessary (Taylor \& Tyler, 2012).

Besides, the principal's role is also a critical factor in achieving school goals (Susanto, 2012). In this connection, teacher performance cannot be separated and indirectly connected with the principal's leadership, supervision, or the guidance process carried out by the principal. A good headmaster's leadership must strive to improve teacher performance through a training program for instructional staff abilities (Syamsul, 2017). As leaders in schools, school principals are individuals who are required to be able to transform their abilities through guidance, guidance, and empowerment to all school members, especially to teachers (Purwanti, Murniati, \& Yusrizal, 2014).

The involvement of school principals and teachers in developing the effectiveness of learning in schools also encourage a higher sense of ownership of their schools, which in turn encourages them to use the available resources efficiently to achieve maximum results. 
Performance is interpreted as the degree of completion of tasks that complement one's work, reflecting how well a person was carrying out the demands of a job (Byars \& Rue, 1991; Simanjuntak, 2005). Furthermore, Syamsudin (2006) provides an understanding of performance as the level of implementation of tasks that can be achieved by someone using existing capabilities and boundaries set to achieve organizational goals. Achievement of this performance can be influenced by factors of ability and motivation (Mangkunegara, 2013). Whereas teacher performance is seen as a set of real behaviors shown by the teacher when giving learning to students (Rahman, 2006). The maximum performance aims to achieve the vision and mission of the world of education (Wibowo, 2015). Good teacher performance will affect student achievement in academic and non-academic fields and will deliver schools in achieving their vision and mission (Kelimeda, Hairudinor, Ridwan, \& Dalle, 2018).

Good teachers will be able to deliver their students to learning achievement. For being a teacher, one's ability must be continuously improved. Because to be a good teacher, many things must be considered and done by a teacher. Good teachers must be able to give attention to their students. Because if teachers pay attention to all their students well, the improvement in student learning achievement will be more easily realized (Kiany \& Shayestefar, 2011). The teacher must also have teaching motivation and confidence in implementing learning to make students enthusiastic about participating in learning (Mahler, Großschedl, \& Harms, 2018). Similarly, teachers must be able to communicate well with students because communication between teachers and students will affect students' motivation to follow the learning process (Bambaeeroo \& Shokrpour, 2017).

Teachers must also carry out evaluations to measure student competence (Dybowski, Sehner, \& Harendza, 2017; Muelasa \& Navarroa, 2015). Teachers must also be able to identify ways of student learning to determine appropriate learning strategies in implementing teaching and learning processes to improve student learning achievement (Tulbure, 2012).
In the current digital era, teachers must master the latest technology to be utilized for teaching and learning (Dalle \& Ariffin, 2018).

In realizing the quality and performance of good teachers, the principal has a vital role. Supervision activities of school principals and teacher achievement motivation will have a psychological effect on teacher morale. Teachers who are satisfied with school principals' supervision and achievement motivation will work voluntarily, which can increase teacher work productivity. Nevertheless, if teachers are not satisfied with the implementation of supervision and achievement motivation of school principals, then teachers will work forced and lack of enthusiasm. As indicated by a negative attitude because they feel unsatisfied, resulting in decreased teacher work productivity (Nitiseminoto, 2009). Therefore, the headmaster is obliged to ensure that supervision can make teachers feel satisfied because the teacher's performance is crucial. After all, it is the beginning of the school's success in achieving its goals (Mathis \& Jackson, 2006).

In addition to conducting supervision, as a school leader, the principal's leadership pattern will also influence the school (Wills, 2016; Aslamiah \& Saleh, 2019). According to Patiara \& Wang (2020), the leadership pattern adopted by a leader of an organization will be crucial in realizing the vision and mission or success of an organization. More specifically, Pantouvakisa \& Vlachos (2020) said that the leadership style implemented by a leader influences the sustainability of the success achieved by an institution because it will affect the working atmosphere and relations between workers in the institution. Thus, efforts to improve teacher performance are inseparable from the school principal and school supervisor's role. Principals in their positions as leaders and supervisors are obliged to foster and develop teachers to become excellent educators and educators. It shows the importance of teacher performance in realizing student achievement and the role of school principals in boosting teacher performance. This study was to analyze the effect of headmaster supervision, headmaster leadership, and teacher achievement motivation on the performance of high school teachers Barito Kuala Regency. 


\section{Material and Methods}

The study population was 408 high school teachers in the Barito Kuala Regency. The study sample was 191 teachers in 16 schools selected by proportional stratified random sampling. Data were collected using a four scale model questionnaire that had been tested for validity and reliability by choosing between one to five answers that best fit the actual conditions. There are four questionnaires used in this study: the principal's supervision questionnaire, the principal's leadership questionnaire, the achievement motivation questionnaire, and the teacher's performance questionnaire by the conceptual relationship model between variables, as shown in Figure 1.

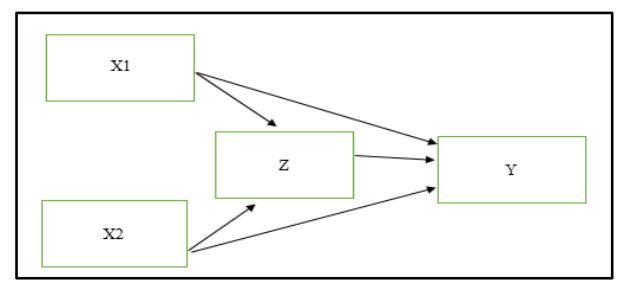

Figure 1. Research model

Per he conceptual model, the analysis uses a pathway to answer six research hypotheses, namely: $\mathrm{H}_{1}$ : there is the principal's leadership influence on teacher performance; $\mathrm{H}_{2}$ : there is an influence of the principal's leadership on achievement motivation; $\mathrm{H}_{3}$ : There is an influence of the principal's supervision on the teacher's performance; $\mathrm{H}_{4}$ : there is an influence of the supervision of the principal on achievement motivation; $\mathrm{H}_{5}$ : there is an influence of achievement motivation on teacher performance; $\mathrm{H}_{6}$ : There is an indirect effect of school principal leadership on teacher performance through teacher achievement motivation; $\mathrm{H}_{7}$ : There is an indirect effect on the supervision of the principal on the performance of teachers through teacher achievement motivation.

\section{Results and Discussion}

The respondents' descriptive statistical analysis of the research variables, namely the supervision of the principal, leadership of the principal, achievement motivation, and teacher performance measured on a scale of 4 shown in Table 1, includes the mean, standard deviation, and categories. Descriptive data in Table 1 indicates that the respondent emphasizes that each variable is in the high category. Interpretation of the path analysis results after going through the stages of testing the analysis requirements with a summary of the results in Table 2 .

Table 1. Mean, mean, standard deviation, and categories of research variables

\begin{tabular}{llll}
\hline \multirow{2}{*}{ Variable } & \multicolumn{2}{l}{ Descriptive } & Category \\
\cline { 2 - 4 } & Mean & Standard Deviation & High \\
\hline Supervision of the Principal & 39.98 & 2.17 & High \\
\hline Principal's Leadership & 58.69 & 3.06 & High \\
\hline Achievement motivation & 40.59 & 2.61 & High \\
\hline Teacher Performance & 31.01 & 2.56 & \\
\hline
\end{tabular}

a. Sample of a Table footnote. (Table footnote)

Table 2. Results of path analysis in structure model 1

Structural 1 Supervision of School Principals, Principal Leadership, Achievement Motivation of Teacher Performance

\begin{tabular}{llll}
\hline Variable & Path coefficient & $\boldsymbol{t}$ & Sig \\
\hline Supervision of the Principal & 0.609 & 109.187 & 0.000 \\
\hline Principal's Leadership & 0.022 & 3.454 & 0.001 \\
\hline Achievement motivation & 0.030 & 2.879 & 0.004 \\
\hline
\end{tabular}


Table 3 Results of path analysis in structure model 2

Structural 2 Supervision of School Principals, Principal Leadership on Achievement Motivation

\begin{tabular}{llll}
\hline Variable & Path coefficient & $\boldsymbol{t}$ & Sig \\
\hline Supervision of the Principal & 0.380 & 13.728 & 0.000 \\
\hline Principal's Leadership & 0.299 & 7.781 & 0.000 \\
\hline
\end{tabular}

Table 4. Summary of the $\mathrm{H}_{1}, \mathrm{H}_{2}, \mathrm{H}_{3}, \mathrm{H}_{4}$, and $\mathrm{H}_{5}$ hypothesis testing decisions

\begin{tabular}{lll}
\multicolumn{1}{c}{ Hypothesis } & sig & Decision \\
\hline $\begin{array}{l}\mathrm{H}_{1}: \text { There is an influence of the principal's supervision on teacher } \\
\text { performance }\end{array}$ & 0.000 & Received \\
\hline $\begin{array}{l}\mathrm{H}_{2} \text { : There is an influence of the principal's leadership on teacher } \\
\text { performance }\end{array}$ & 0.001 & Received \\
\hline $\mathrm{H}_{3}$ : There is achievement motivation in teacher performance & 0.004 & Received \\
\hline $\begin{array}{l}\mathrm{H}_{4}: \text { There is an influence of the supervision of the principal on } \\
\text { achievement motivation }\end{array}$ & 0.000 & Received \\
\hline $\begin{array}{l}\mathrm{H}_{5}: \text { There is an influence of the principal's leadership on } \\
\text { achievement motivation }\end{array}$ & 0.000 & Received \\
\hline
\end{tabular}

Table 5. Summary of $\mathrm{H}_{6}$ dan $\mathrm{H}_{7}$ hypothesis testing decisions

\begin{tabular}{llll}
\hline \multirow{2}{*}{ Hypothesis } & \multicolumn{2}{l}{ Path coefficient } & \multirow{2}{*}{ Decision } \\
\cline { 2 - 3 } & Direct & Not direct & \\
\hline $\begin{array}{l}\mathrm{H}_{6} \text { : There is an indirect effect on the supervision } \\
\text { of the principal on teacher performance through } \\
\text { achievement motivation }\end{array}$ & 0.609 & 0.011 & Received \\
\hline $\begin{array}{l}\text { H: There is an indirect effect of school principal } \\
\text { leadership on teacher performance through } \\
\text { achievement motivation }\end{array}$ & 0.022 & 0.009 & Received \\
\hline
\end{tabular}

The path analysis results shown in Table 2 and Table 3 are to answer the five research hypotheses formulated. The decision of the analysis results in Table 4 and Table 5. Table 4 summarizes the decision of hypothesis 1 through hypothesis 5 with a critical significance value of less than 0.05 , then the hypothesis is accepted. Table 5 summarizes the decision of testing hypothesis 6 through hypothesis 7 , which is an indirect effect. Based on the results of the analysis in the Table above in this study successfully found intervariable influences that can be explained as follows.

There is an influence of the principal's supervision, leadership of the principal, achievement motivation on teacher performance

According to Glickman (1981) supervision is an effort to help teachers develop the ability to achieve learning goals. According to
(Komariah, 2011) "supervision can mean supervision carried out by experts/professionals so that they can provide improvements and enhancements/coaching so that learning can be done well and with quality." Supervision aims to help teachers develop their abilities to achieve learning goals designed for their students. Through this supervision, the principal can determine the necessary conditions to ensure learning objectives (Mulyasa, 2009).

Supervision is necessary for teachers to improve their ability to manage the learning process effectively and efficiently (Bafadal, 2009). As a leader and supervisor for the teacher, the principal influence improving teacher performance. The principal's role as a supervisor is to increase the learning program's overall success by helping teachers solve the classroom (Sobri, 2013). This finding is per research conducted by Syarif (2011) con- 
cluding that there is a positive influence between school principals' supervision on teacher performance. Other research also states a positive relationship between school principals' supervision and the performance of public elementary school teachers in Tanjung District, Tabalong Regency (Suhaimi, 2017), and Teluk Betung Selatan District, Bandar Lampung. The same thing was proven by Saani (2013) in Ghana, West Africa. According to (Ernilawati, 2011), there is a positive and significant result between school principals' supervision and achievement motivation with the Principals' supervision in Banjar District.

Significant relationships between principals' academic supervision and teacher performance also, found in Tsanawiyah Tabek Madrasah, Pariangan District Tanah Datar Regency (Hasanah \& Kristiawan, 2019), SMP Negeri 2 Lubuk Pakam (Ismail, 2019), and in all elementary school teachers and principals in Sumedang Regency (Kodariah, Herawan, \& Sutrasih, 2016). Furthermore, the supervision of the principal also made a compelling contribution of $79 \%$ to teacher performance, which included the preparation of lesson plans, opening learning, learning processes, closing learning, evaluating learning outcomes, and evaluating learning in Sewon District, Bantul, Yogyakarta (Supriono, 2014).

The influence of principal school supervision was also proven to significantly affect SMKN 2 teachers' performance in Padang, West Sumatra (Afriyanli \& Sabandi, 2020). A leader indeed becomes a benchmark for all school residents to develop their potential. Indicators of school principals are useful to observe through three things (Greenfield in (Mulyasa, 2012)). Namely, the school's first commitment to the school's vision in carrying out its duties and functions, secondly making the school's vision a guide in managing and leading the school, and thirdly always focusing its activities on learning and teacher performance in class. This study is per research conducted by (Suarsana, 2009) which states that there is a strong relationship between leadership and teacher performance. Besides (Ayu Kusumayani, 2013) also stated that there was a positive and signif- icant contribution between leadership behavior towards the performance of teachers of state high schools in Amlapura City. In SMK Negeri 1 Gowa, the principal's leadership style positively and significantly influences the teacher performance in terms of directing, coaching, and supporting styles (Sukmawati, Jamaluddin, Niswaty, \& Asmanurhidayani, 2018) - also proved in 13 other Vocational Highs in Gunungkidul Regency, Yogyakarta (Setiyati, 2014).

The influence of school principal leadership has also been proven to have a significant effect on teacher performance in elementary schools in the city of Bandung, West Java(Resawati \& Larashati, 2016) and a significant and positive effect on teacher performance in Bonang District, Demak, Central Java (Achmadi, 2012). Principal's leadership has a positive and significant influence on teacher performance in MTsN Batudaa, Gorontalo (Ngiode, 2016). As a leader, the principal, as explained by the Office of Education (Mulyasa E., 2004), includes educators, managers, administrators, supervisors, leaders, innovators, and motivators. The role of an indicator is to improve and enhance the teaching and learning situation.

Henry Alexander Murray first formulated the concept of achievement motivation, then developed by David McClelland by bringing the term need for achievement (Need for Achievement) as the beginning of achievement motivation (Hikmat, 2009). Achievement motivation is encouragement from within to overcome all challenges and obstacles to achieve goals (Usman, 2006). This impetus is on every human being to achieve the results of their activities or work results to the maximum (Notoadmodjo, 2009). High or low achievement motivation determines situations where someone will maximize their performance or not (McInerney, Maehr, \& Dowson, 2004).

The findings in the study of the relationship between positive achievement motivation on teacher performance supported by statements made by (Suhaimi, 2017) that there is a positive relationship between achievement motivation and teacher's performance of public elementary school teachers in Tanjung district, 
Tabalong Regency. The results of research conducted in line with several previous studies, including (Rismawan, 2015) about the influence of supervision of school principals and teacher achievement motivation on teacher performance, produce a conclusion that based on the results of structural model analysis obtained a regression coefficient of 0.39 . It indicates the influence of independent variables (teacher achievement motivation) on the dependent variable (teacher teaching performance). Research by Wardani (2018) shows that achievement motivation has a positive and significant effect on the performance of Special Inclusive Assistance Teachers in Metro City, Lampung. Furthermore, it was also found that achievement motivation had a significant relationship to teacher performance even though it was fragile in MAN 2 Tanjung Pura, Langkat (Ardiansyah, 2018). MAN 2 in Probolinggo Regency at $8.6 \%$ (Arifin, 2018).

Supervision is an effort to provide services and assistance to teachers individually and in groups to improve teaching (Sahertian, 2008). These efforts include encouraging, coordinating, and demanding continuous teacher growth in a school, both individually and in groups, in a better understanding. More effective actions in the teaching function can encourage and guide each student's growth individually. It also encourages sustainability towards smart and productive participation in the life of modern democratic societies (Priansa \& Setiana, 2018).

The data analysis shows that the path coefficient between school principals' supervision on the achievement motivation of high school teachers in Barito Kuala Regency is 0.380 and is positive by a significance level of $0.000<0.05$. It means that the Principal's Supervision affects Teacher Achievement Motivation. Thus, the principal's level of supervision will affect the level of motivation and achievement of teachers.

Per research conducted by (Rismawan, 2015) concluded that the Effect of Supervision of School Principals on the Achievement Motivation of Public Primary School Teachers in the Education and Culture Office of Kertasari District of Bandung Regency obtained a regression coefficient of 0.36 (positives give). It shows the positive influence of the independent variable (principal school supervision) on the dependent variable (teacher achievement motivation). Also, it obtains a t- value of 3.86. Besides, research from (Lubis, 2018) states there is a positive direct effect of perceptions about school principals' supervision on achievement motivation.

Principal's leadership can also be a factor in increasing teacher achievement motivation. By using an appropriate leadership style, teachers are expected to be motivated to do their jobs better to improve teachers' competencies and achievements. The findings in this study are a positive and significant influence between the school principal's leadership on the achievement motivation of high school teachers in Barito Kuala Regency. It is in line with research conducted by (Veronika N., 2016) that the Principal's Leadership affects a positive and significant Achievement Motivation construct. Teachers with a $60 \%$ contribution are in the high category. It shows that the principal's leadership variable has a positive and significant influence on Teacher Achievement Motivation. Also, research from (Novitasari, 2017) shows that there is a significant influence partially on the Principal's Leadership on the Achievement Motivation of Vocational School teachers in East Oku Regency, South Sumatra Province evidenced by $\mathrm{t}$ count $>\mathrm{t}$ table or $4.839>1.984$ and sig. $0.000<0.05$. One approach that can be done by school principals in fostering teacher achievement motivation is through self-explorer, human relations-explorer, and good communication, as has been done at SMPK Mardi Wiyata 2 and SMPK Cor Jesu. They are all located in Malang City, East Java (Luangsithideth, 2013).

\section{There is an indirect effect of the principal's supervision on teacher performance through achievement motivation and the indirect ef- fect of the principal's leadership on teacher performance through achievement motiva- tion}

The research results in this study were supported by Cascio W.F. (2006), in their statement, concluded that ability and motivation are factors that interact with the performance. The opinion of Cowley in Wahjosumidjo (2010) also 
concludes that "The leader is who succeeds for getting others to follow him," where a leader functions to move others so that they consciously want to do what the leader wants. The existence of enthusiasm for work, synergistic cooperation between elements in the school, interest in development and progress of education, a conducive work atmosphere, the development of the quality of professionalism of teachers and the improvement of the quality of graduates is mostly determined by the leadership of the principal school quality.

From testing on the effect of the principal's supervision on teacher performance through achievement motivation, the principal's professional assistance to a teacher who has problems implementing the learning process can help teachers fully realize their weaknesses and shortcomings. Per previous research conducted by (Royani, 2015) states that significantly academic supervision and supervisor personality competency, as well as achievement motivation, directly influence teacher performance, so also achievement motivation is proven to be a mediator of academic supervision and supervisor personality competency on teacher performance.

\section{Conclusion and Recommendation}

The conclusions from the results of the research in Barito Kuala Regency are as follows: 1) there is an influence of school principal leadership on teacher performance; 2) there is an influence of the principal's leadership on achievement motivation; 3 ) there is an influence of the supervision of the principal on teacher performance; 4) there is the influence of the supervision of the principal on achievement motivation; 5) there is an influence of achievement motivation on teacher performance; 6) there is an indirect effect of the principal's leadership on teacher performance through teacher achievement motivation; 7) there is an indirect effect on the supervision of school principals on teacher performance through teacher achievement motivation.

It is suggested to the Teachers and Principals of SMAN Schools in Barito Kuala Regency, as well as the Head of the Office of Education and Culture of South Kalimantan Province to be able to help and maintain improving the value of performance by fostering and guiding teachers in carrying out their duties, providing suggestions and solutions to problems faced by teachers, invites teachers to improve unfavorable conditions through cooperation and tolerance. Besides, policymakers such as the Provincial Education Office are expected to provide school principals training in carrying out their duties as supervisors and leaders in schools. With proper training, expectantly, the quality of supervision, and the leadership pole implemented by the principal will be better. So, automatically, the quality and performance of teachers will improve.

It is recommended that other researchers conduct similar research to this study by raising the same variable in different places and using it as literature and sources of information to conduct further research in the field of education.

Furthermore, other researchers are advised to conduct other studies by testing the independent variables in addition to the variables that have been tested in this study. It is critical to do because there are sharing other factors that theoretically have a relationship with teacher performance. Thus, these factors need to be tested and empirically proven. The results of these studies will be able to complement the results of this study. Later, the research results can be used to determine programs or policies related to improving teacher performance. The results of these activities and programs will be optimized by basing these activities and programs on information empirically confirmed.

\section{Acknowledgment}

Our gratitude and appreciation extend to all parties involved and contributed in completing this research.

\section{References}

Achmadi. (2012, December). Relations between principal leadership, achievement motivation, and compensation with the performance of elementary school teachers. Journal of Education Management, 1(3), 283-294. doi:https://doi.org/10.26877/jmp.v1i3.391 
Afriyanli, H. K., \& Sabandi, A. (2020). The effect of principal supervision on teacher performance. Journal of Management, Leadership and Education Supervision, 5(1), 51-55.

Alpian, Y., Anggraeni, S. W., Wiharti, U., \& Soleha, N. M. (2019, February). The importance of education for human. Journal of Buana Pengabdian, 1(1), 66-72. doi:10.36805/jurnalbuanapengabdian.v1i1.581

Ardiansyah, F. (2018). The relations between achievement motivation and teacher performance in MAN 2 Tanjung Pura, Langkat. Medan: UIN Sumatera Utara.

Arifin, M. H. (2018, March). The influence of principal leadership style, achievement motivation, and school climate on the teacher performance in MAN 2 of Probolinggo Regency. Journal of Indonesia Social Science Education, 3(1), 1-3.

Aslamiah, H. P., \& Saleh, M. (2019). Contribution of Principal Transformational Leadership, Work Motivation, Through Satisfaction with OCB Teachers. Journal of K6, Education, and Management (j-K6EM), (2), 159-165.

Ayu Kusumayani, N. N. (2013). Contribution of principal leadership behavior, teacher work satisfaction, and teacher commitment to teacher performance in SMA Negeri in Amlapura City. E-Journal Graduate Program of Educational University of Ganesha, 1-8.

Bafadal. (2009). Human resources management. Jakarta: Bumi Aksara.

Bambaeeroo, F., \& Shokrpour, N. (2017). The impact of the teachers' non-verbal communication on success in teaching. Journal of Advances in Medical Education \& Professionalism, 5(2), 51-59.

Byars, L. L., \& Rue, L. W. (1991). Human resources management (3 ed.). Boston: Irwin, Inc.

Dalle, J., \& Ariffin, A. M. (2018). The Impact of Technologies in Teaching Interaction Design. Journal of Advanced Research in Dynamical and Control System, 04(special issue), 17791783.

Dybowski, C., Sehner, S., \& Harendza, S. (2017). Influence of motivation, self-efficacy, and situational factors on the teaching quality of clinical educators. BMC Medical Education, 17(1), 84-95 doi:https://doi.org/10.1186/s12909-017-0923-2

Ernilawati. (2011). The relation between principal supervision and achievement motivation on teacher performance in SMPLB of Banjar Regency. Banjarmasin: FKIP UNLAM.

Glickman, C. (1981). Development supervision (alternative practice for helping teachers improve instruction). Virginia: ASCD.

Gusman, H. E. (2014, June). The relations between headmaster leadership style and teacher performance in Public Junior High School in Palembayan, Agam. Bahana of Education
Management: Journal of Education Administration, 2(1), 293.

Hasanah, M. L., \& Kristiawan, M. (2019, November). Academic supervision and teacher performance. Tadbir: Journal of Education Management Studies, 3(2), 97-112. doi:http://dx.doi.org/10.29240/jsmp.v3i2.1159

Hikmat. (2009). Educational psychology. Jakarta: Bumi Aksara.

Ismail, H. (2019). The relation between principal academic supervision and school culture on teacher performance in SMPN 2 Lubuk Pakam. Medan: UIN Sumatera Utara.

Kelimeda, Hairudinor, Ridwan, M. N., \& Dalle, J. (2018). The effect of motivation, job satisfaction, and job discipline toward employee performance of PT. Buma Perindahindo At Lng Tangguh Site, Teluk Bintuni Regency, West Papua, Indonesia. European Journal of Human Resource Management Studies, 2(1), 49-73. doi:10.5281/zenodo.2040456

Kiany, G. R., \& Shayestefar, P. (2011). High school students' perceptions of EFL teacher control orientations and their English academic achievement. British Journal of Educational Psychology, 81(3), 491-508. doi:https://doi.org/10.1348/000709910X522177

Kodariah, W., Herawan, E., \& Sutrasih, C. (2016). Principal academic supervision, teacher achievement motivation, and teaching teacher performance. Journal of Education Administration, XXIII(2), 123-133.

Komariah, E. \&. (2011). Educational administration. Bandung: Alfabeta.

Li, W., Bhutto, T. A., Xuhui, W., Maitlo, Q., Zafar, A. U., \& Bhutto, N. A. (2020). Unlocking employees' green creativity: The effects of green transformational leadership, green intrinsic, and extrinsic motivation. Journal of Cleaner Production, 255, 1-10. doi:https://doi.org/10.1016/j.jclepro.2020.120229

Liden, R. C. (2001). Managing Individual Performance in Work Groups. Journal of Human Resource Management, 40(1), 63-72.

Luangsithideth, V. (2013, September). Headmaster leadership in fostering teacher achievement motivation. Journal of Education of Humaniora, 1(3), 213-220.

Lubis, P. K. (2018). The effect of perception on principal supervision, organizational culture, and achievement motivation on teacher performance in private MTS Sub Rayon 44 in Deli Serdang Regency. Journal of Tarbiyah, 109-131.

Mahler, D., Großschedl, J., \& Harms, U. (2018). Does motivation matter? The relationship between teachers' self-efficacy and enthusiasm and students' performance. Plos One, 13(11), e0207252. doi:https://doi.org/10.1371/journal.pone.0207252 
Mangkunegara, A. P. (2013). Human reseources management. Bandung: PT Remaja Rosdakarya.

Mathis, R. L., \& Jackson, J. H. (2006). Human resources management (10 ed.). Jakarta: Salemba Empat.

McInerney, D. M., Maehr, M. L., \& Dowson, M. (2004). Motivation and culture. In C. D. Spielberger (Ed.), Encyclopedia of Applied Psychology (pp. 631-639). Academic Press. doi:https://doi.org/10.1016/B0-12-657410-3/00206-3

Muelasa, A., \& Navarroa, E. (2015). Learning strategies and academic achievement. Procedia - Social and Behavioral Sciences, 165, 217- 221. doi:10.1016/j.sbspro.2014.12.625

Mulyasa. (2009). Competence and profession of teacher. Bandung: Alfabeta.

Mulyasa. (2012). Management and principal leadership. Jakarta: Bumi Aksara.

Mulyasa, E. (2004). School based management. Bandung: PT. Remaja Rosdakarya.

Ngiode, S. (2016). Headmaster leadership, work motivation, and work discipline on the teacher performance of MTsN Batudaa, Gorontalo. Tadbir: Journal of Islamic Education Management, 4(2), 127-137.

Nitiseminoto, A. (2009). Personnel management (MSDM). Jakarta: Ghalia.

Notoadmodjo, S. (2009). Human resources development. Jakarta: Rineka Cipta.

Novitasari, S. D. (2017). The effect of principal leadership, school climate, and achievement motivation on teacher commitment. Lampung: FKIP Unila.

Pantouvakisa, A., \& Vlachos, I. (2020). Talent and leadership effects on sustainable performance in the maritime industry. Transportation Research Part D: Transport and Environment, 86 ,

$1-12$. doi:https://doi.org/10.1016/j.trd.2020.102440

Patiara, A., \& Wang, Y. (2020). Managers' leadership, compensation and benefits, and departments' performance: Evidence from upscale hotels in Australia. Journal of Hospitality and Tourism Management, 42, 29-39. doi:https://doi.org/10.1016/j.jhtm.2019.11.005

Priansa, D. J., \& Setiana, S. S. (2018). Educational supervision management. Bandung: Pustaka Setia.

Purwanti, K., Murniati, A. R., \& Yusrizal. (2014). Principal role in improving teacher performance in SMPN 2 Simeulue Timur. Journal of Scientific Didaktika, XIV(2), 390-400.

Rahman, N. (2006). The strategic role of the principal in improving education quality. Jatinangor: Alqaprint.

Resawati, R., \& Larashati, I. (2016, October). The effect of principal leadership, teacher competence, and compensation on teacher performance. Journal of Economy, Business \& Entrepreneurship, 10(2), 132-148.
Rismawan, E. (2015). The relation of principal supervision and achievement motivation on teaching performance of a teacher. Jurnal Administrasi Pendidikan, XXII(1), 114-132.

Royani, A. (2015). Teacher achievement motivation as a mediator effect of academic supervision and supervisor characteristic competence on teacher performance in state SMK of Semarang Regency. Semarang: State University of Semarang.

Saani, A. J. (2013, December). Influence of compensation and supervision on private primary school teachers' work performance in the Ashaiman Municipality. International Journal of Business and Social Science, 4(17), 1-10.

Sahertian. (2008). Basic concept \& educational supervision technique in terms of human resources development. Jakarta: Rineka Cipta.

Setiyati, S. (2014). The effect of principal leadership, work motivation, and school culture on teacher performance. Journal of Technology and Vocational Education, 22(2), 200-207. doi:https://doi.org/10.21831/jptk.v22i2.8931

Simanjuntak, P. J. (2005). Management and work evaluation. Jakarta: Faculty of Economics UI Press.

Sobri, A. Y. (2013, March). Teacher professionalism supervision in improving learning quality. Journal of Education Management, 24(1), 9-20.

Suarsana, I. K. (2009). Contribution of principal leadership behavior and teacher work enthusiast on teacher performance improvement in state SMA of Gianyar Regency. Undiksha: -

Suhaimi, W. \&. (2017). The relation between principal supervision and achievement motivation with teacher performance in state elementary school in Tanjung Subdistrict, Tabalong Regency. National Seminar Proceeding of S2DMP, 1-6.

Sukmawati, Jamaluddin, Niswaty, R., \& Asmanurhidayani. (2018, July-December). The influence of the headmaster's leadership style on teacher performance. Journal Office: Journal of Scientific Thoughts and Office Administration Education, 4(2), 91-102. Retrieved from http://ojs.unm.ac.id/jo

Supriono, E. (2014). The influence of principal supervision on the performance of elementary school teachers in Sewon Subdistrict, Bantul, Yogyakarta. Yogyakarta: State University of Yogyakarta.

Susanto, H. (2012, June). Factors influenced teachers' performance in Vocational High School. Jurnal Pendidikan Vokasi, 2(2), 197-212.

Syamsudin. (2006). Human resources management. Bandung: Pustaka Setia. 
Syamsul, H. (2017, December). The implementation of principal leadership in improving teacher performance in Junior High School. Journal of Idaarah, 1(2), 275-289.

Syarif, M. (2011, January). The effect of interpersonal communication and principal supervision on teacher performance. Media Academica, 26(1), 12-19.

Taylor, E. S., \& Tyler, J. H. (2012). The effect of evaluation on teacher performance. American Economic Review. doi:https://doi.org/10.1257/aer.102.7.3628

Tulbure, C. (2012). Learning styles, teaching strategies, and academic achievement in higher education: A crosssectional investigation. Procedia - Social and Behavioral Sciences, $\quad 33, \quad 398 \quad$ - $\quad 402$. doi:https://doi.org/10.1016/j.sbspro.2012.01.151

Usman, H. (2006). Management theory, practice, and educational research. Jakarta: Bumi Aksara.
Veronika, N., W. H. (2016). Supervise supervisor academic supervision and principal leadership through achievement motivation as the mediator on teacher performance of state Vocational High School in Ende Regency. Journal of Unnes Education Management, 5(1), 42-54.

Wardani, E. S. (2018). The influence of critical managerial skills, organizational culture, and achievement motivation on the performance shadow teacher in inclusion primary school. Bandar Lampung: University of Lampung.

Wibowo, D. H. (2015, September). Achievement motivation in relation to teacher performance. Scholaria, 5(3), 65-74. doi:10.24246/j.scholaria.2015.v5.i3.p65-74

Wills, G. (2016). Principal leadership changes and their consequences for school performance in South Africa. International Journal of Educational Development, 51, 108124. doi:https://doi.org/10.1016/j.ijedudev.2016.08.005 